\title{
Interaction of Quinacrine Mustard with Whole and Partially Deproteinized Calf Thymus Deoxynucleoproteins
}

\author{
RITVA-KAJSA SELANDER
}

The Folkhälsan Institute of Genetics, P.0. Box 819, SF-00101 Helsinki 10, Finland

Spectrophotometric and fluorimetric studies were made on the binding of quinacrine mustard to whole and partially deproteinized calf thymus deoxynucleoproteins. Proteins were extracted from the deoxynucleoprotein with $0.2,0.3,0.4$, 0.6 , and $3 \mathrm{M} \mathrm{NaCl}$ in the presence of $6 \mathrm{M}$ urea and $0.04 \mathrm{M}$ sodium bisulfite. The proteins were further separated from the remaining deoxynucleoprotein on Bio-Gel A-50 columns. A decrease in the fluorescence intensity of quinacrine mustard was observed as the proteins were removed from the deoxynucleoprotein. The greatest decrease was obtained when most of the proteins (extraction with 0.6 or $3 \mathrm{M} \mathrm{NaCl}$ in 6 $M$ urea and $0.04 \mathrm{M}$ sodium bisulfite) were removed from the DNA core. At low dye-topolymer ratios the removal of all the histones ( $\mathrm{NaCl}$ concentrations above $0.4 \mathrm{M}$ in $6 \mathrm{M}$ urea and $0.04 \mathrm{M}$ sodium bisulfite) caused a marked change in the fluorescence intensity of quinacrine mustard. Probably the proteins compete for the binding of the dye to deoxynucleoprotein. Natural and artificial deoxynucleoproteins reacted differently with quinacrine mustard. This probably reflects structural differences between the polymers. When quinacrine and quinacrine mustard were mixed with whole deoxynucleoprotein, differences occurred in the absorption and fluorescence properties of the two dyes. This suggests that the two dyes must interact in different ways with the polymer.

Studies on the chemical composition of chromosomes in eucaryotes show that several kinds of proteins, both basic (histones) and acidic (nonhistones), as well as RNA, are bound to chromosomal DNA.' Various techniques have been used to investigate the structure of these chromosomal components. ${ }^{2-4}$ The interaction between small molecules or dyes with macromolecules has also provided information about the molecular organization of chromosomes.
Dyes that have been found useful include acridine derivatives, such as acridine orange, ${ }^{5-7}$ proflavine, ${ }^{8-10}$ quinacrine and quinacrine mustard. ${ }^{6,711-14}$ The interaction of other dyes such as azure $A,{ }^{15}$ ethidium bromide, ${ }^{16}$ and toluidine blue ${ }^{17}$ with macromolecules has also been investigated.

A fair amount of evidence indicates that quinacrine and quinacrine mustard bind differentially to the bases in nucleic acids (see reviews above). An enhancement of the fluorescence intensity of these two dyes occurs with adenine residues, whereas guanine residues decrease the fluorescence intensity of the dyes in solution. Weisblum and de Haseth ${ }^{7}$ postulated that the fluorescence intensity of bound quinacrine also reflects the pattern of base-repetition in the nucleic acid. The binding of the dye also depends on the strandedness of the nucleic acid. ${ }^{14,18}$ Studies on the interaction between quinacrine mustard and proteins (histones) in solution showed that the dye-protein interaction depends on the physical state of the protein. ${ }^{18}$

This paper describes the absorption and fluorescence properties of quinacrine mustard bound to deoxynucleoproteins in solution. Parallel studies were made with the related dye, quinacrine. The data refer to staining of metaphase chromosomes in situ with fluorochromes.

\section{EXPERIMENTAL}

Deoxynucleoproteins. DNP* from calf thymus was isolated according to the method of Zubay and Doty. ${ }^{19}$ The DNP was characterized by a low $320 \mathrm{~nm}$ to $260 \mathrm{~nm}$ ratio of absorbance $(\leq 0.05)$ and by a protein to DNA ratio of 
Table 1. Chemical characterization of DNA, whole DNP and partial DNP's from calf thymus. Extraction performed with urea, $\mathrm{NaHSO}_{3}$, and increasing amounts of $\mathrm{NaCl}$.

\begin{tabular}{llllll}
\hline Sample & $\begin{array}{c}E_{280^{a}}{ }^{a} \\
\left(10^{-3}\right)\end{array}$ & $\begin{array}{l}E_{280} / \\
E_{230}\end{array}$ & $\begin{array}{l}E_{280} / \\
E_{230}\end{array}$ & $\begin{array}{l}\text { Protein/ } \\
\text { DNA ratio }\end{array}$ & $\begin{array}{l}\text { \% Protein } \\
\text { remaining }\end{array}$ \\
\hline DNP (whole) & 7.7 & 1.16 & 0.71 & 1.62 & 100 \\
DNP (extracted) & & & & & \\
0.2 M NaCl & 7.1 & 1.23 & 0.83 & 0.68 & 43 \\
0.3 M NaCl & 7.1 & 1.52 & 1.13 & 0.60 & 32 \\
0.4 M NaCl & 7.0 & 1.53 & 1.31 & 0.50 & 23 \\
0.6 M NaCl & 6.8 & 1.62 & 1.27 & 0.37 & 14 \\
3 M NaCl & 6.8 & 1.62 & 1.27 & 0.19 & 7 \\
DNA $^{b}$ & 6.8 & 1.95 & 1.93 & 0.00 & 0 \\
\hline
\end{tabular}

angerer and Moudrianakis. ${ }^{10} b$ DNA from calf thymus was isolated as described elsewhere. ${ }^{20}$

approximately 1.6 (Table 1). The whole DNP was stored in $0.7 \times 10^{-3} \mathrm{M}$ potassium phosphate buffer, pH 8.0 at $-20^{\circ} \mathrm{C}$.

Partial deoxynucleoproteins. Partial DNP's were prepared by selective dissociation of pro. teins with $\mathrm{NaCl}$, urea, and sodium bisulfite. ${ }^{21}$

Freshly prepared chromatin was dialyzed against $6 \mathrm{M}$ urea and placed in a buffer solution containing both $6 \mathrm{M}$ urea and $0.04 \mathrm{M}$ sodium bisulfite at $\mathrm{pH} 7.8$ and with increasing amounts of $\mathrm{NaCl}$. The final $\mathrm{NaCl}$ concentrations were 0.2 , $0.3,0.4,0.6$, and $3 \mathrm{M}$. The solutions were stored for $24 \mathrm{~h}$ at $4{ }^{\circ} \mathrm{C}$ before gel filtration in the same salt concentration. Bio-Gel A-50 (BIO. RAD Laboratories, U.S.A.) columns equili-

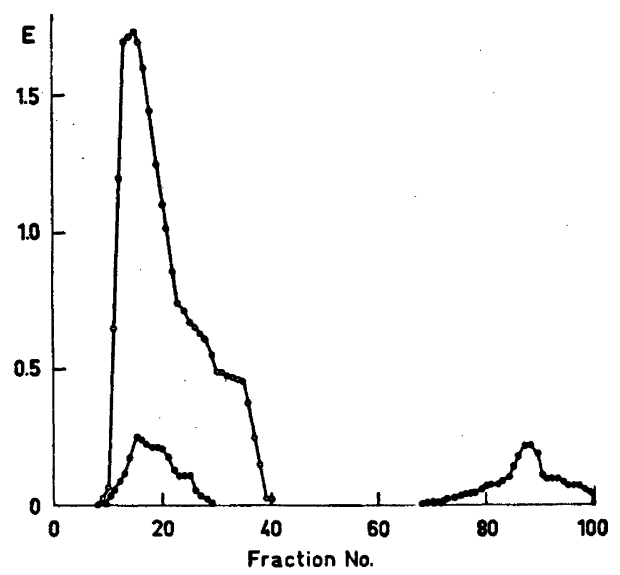

Fig. 1. Chromatography of deoxynucleoprotein on Bio-Gel A-50. The partially deproteinized DNP (cf. Experimental) in $0.6 \mathrm{M} \mathrm{NaCl}, 6 \mathrm{M}$ urea and $0.04 \mathrm{M} \mathrm{NaHSO}_{3}$ was applied to a Bio-Gel A.50 column and step-wise eluted (2.5 ml portions) with the same salt solution. The DNP (O) was estimated at $260 \mathrm{~nm}$ and the protein (O) at $400 \mathrm{~nm}$ according to Bonner et al. ${ }^{2 a}$ brated at the same $\mathrm{NaCl}$, urea, and $\mathrm{NaHSO}_{3}$ concentrations were used to separate the dissociated proteins. Samples of $20 \mathrm{ml}$ containing approximately 60 to $80 E_{200}$ units DNP were placed on these columns, $35 \mathrm{~cm}$ in length and $2.5 \mathrm{~cm}$ in diameter. The rate of elution at $4^{\circ} \mathrm{C}$ was approximately $0.5 \mathrm{ml} / \mathrm{min}$. The DNP peak separated off first followed by the protein peak (Fig. 1). The recovery of the DNP was approximately $75 \%$ and that of the protein 60 to $70 \%$. The DNP was assayed at $260 \mathrm{~nm}$. It was not possible to assay the proteins at $230 \mathrm{~nm}$ since $\mathrm{NaHSO}_{3}$ absorbs strongly at this wavelength. The proteins were therefore assayed by measur. ing the turbidity at $400 \mathrm{~nm}$ after precipitation with trichloroacetic acid." The partial DNP's were stored in $2 \times 10^{-4} \mathrm{M}$ EDTA, $\mathrm{pH} 6.2$ and the proteins in $1 \%$ acetic acid.

Dyes, The dyes Quinacrine and Quinacrine Mustard* were gifts from Sterling.Winthrop Research Institute, U.S.A. The structures of<smiles>CCNc1c2ccc(Cl)cc2nc2ccc(OC)cc12</smiles>

Quinacrine (Q)<smiles>CCNc1c2ccc(Cl)cc2nc2ccc(OCCN(CC)CCCl)cc12</smiles>

Quinacrine Mustard (QM)

(I)

* In this publication deoxynucleoprotein = DNP; Quinacrine=Q; Quinacrine Mustard $=\mathbf{Q M}$.

Acta Chem. Scand. B 28 (1974) No. 8 
the two dyes are shown in (I). Spectral characteristics of QM have been reported earlier. ${ }^{12}$ The absorption and fluorescence properties of $Q$ were almost identical with those of QM. The absorption spectra of $Q$ showed peaks at 280 , 345,424 , and $435 \mathrm{~nm}$. The molar extinction coefficient at $424 \mathrm{~nm}$ was $8.5 \times 10^{3} .^{23}$ With excitation at $436 \mathrm{~nm}$ a fluorescence peak was obtained at $514 \mathrm{~nm}{ }^{10}$ The fluorescence intensity of $Q$ was greatest at $\mathrm{pH} 11$ to 12 .

Proteins. Calf thymus histone fractions IIA (intermediate histone fraction), III (lysine-rich histones) and IV (arginine-rich histones) were purchased from Sigma Chemical, U.S.A.

Analysis. DNA content was determined by the absorption at $260 \mathrm{~nm}$ using the molar extinction coefficients for whole and partial DNP's in Table 1, and cross-checked with the diphenylamine reaction. ${ }^{24}$ Proteins were determined by the method of Lowry et al. ${ }^{25}$ calibrated against bovine serum albumin.

The methods of absorption and fluorescence measurements have been described elsewhere. ${ }^{12}$ The fluorescence intensity was measured at 514 $\mathrm{nm}$ with excitation at $436 \mathrm{~nm}$. Before any titration measurements the DNP samples were dialyzed against $0.7 \times 10^{-8} \mathrm{M}$ potassium phosphate buffer, $\mathrm{pH}$ 8.0 or against $0.05 \mathrm{M}$ Tris solution, $\mathrm{pH} 7.5$ ( $c f$. Experimental). In absorption measurements an identical DNP sample without dye was used in the reference cell to eliminate any contribution to the absorption by DNP. DNP did not disturb the fluorescence measurements at $514 \mathrm{~nm}$.

The fluorescence data were expressed as the percentage change $(\Delta \%)$ relative to the intensity of the fluorescence intensity of the dye alone.

Reconstitution of proteins and $D N A$. Artificial DNP's were prepared according to the method described by Bonner et al. ${ }^{22}$ In these experiments histone fractions IIA, III, and IV (Sigma) and calf thymus DNA were used. The histone-toDNA mass ratios in the artificial nucleohistones were: DNA-IIA 1.24, DNA-III 1.22, and DNAIV 0.96 .

Analytical disc electrophoresis. Free proteins from the Bio-Gel A-50 runs were lyophilized and dissolved in $10 \mathrm{M}$ urea, $0.9 \mathrm{M}$ acetic acid. Histones were removed from whole and partial DNP's by acid extraction (0.2 $\left.\mathrm{M} \mathrm{H}_{2} \mathrm{SO}_{4}\right)$ and dialyzed against $6 \mathrm{M}$ urea, $0.9 \mathrm{M}$ acetic acid. Disc electrophoresis was carried out using the method of Panyim and Chalkley. ${ }^{26}$ The samples $(50-150 \mu \mathrm{g})$ were applied on the gels $(0.6$ $\mathrm{cm} \times 10 \mathrm{~cm}$ ), which consisted of $15 \%$ polyacrylamide in $2.5 \mathrm{M}$ urea, $0.9 \mathrm{M}$ acetic acid, pH 2.8, and were pre-electrophoresed for $2 \mathrm{~h}$ at $200 \mathrm{~V}$. Electrophoreses were carried out at $200 \mathrm{~V}$ for $2 \mathrm{~h}$. Both upper and lower buffers were $0.9 \mathrm{M}$ acetic acid. The gels stained in Amido-Black $10.5 \%$ Amido-Black in 50\% ethanol, $7 \%$ acetic acid) for $4 \mathrm{~h}$ and destained by electrophoresis in $7 \%$ acetic acid. Bovine serum albumin was added as a marker protein.

\section{RESULTS}

Composition of deoxynucleoprotein samples. Fig. 1 depicts a run on a Bio-Gel A-50 column with DNP extracted with $0.6 \mathrm{M} \mathrm{NaCl}, 6 \mathrm{M}$ urea, and $0.04 \mathrm{M} \mathrm{NaHSO}$. The DNP separated first $\left(E_{260}\right)$ followed by the dissociated proteins $\left(E_{100}\right)$.

The DNA and protein content in the various samples were analyzed spectrophotometrically and a summary of the results is shown in Table 1. The electrophoretic patterns for the different protein fractions are shown in Fig. 2. Fig. 2a depicts the pattern obtained when the histone fractions IIA, III, and IV (Sigma) were mixed together.

$\mathrm{NaCl}$ concentrations of $0.2 \mathrm{M}$ and $0.3 \mathrm{M}$ (urea, $\mathrm{NaHSO}_{3}$ ) removed, respectively, $57 \%$ and $68 \%$ of the proteins from the DNA core (Table 1). These proteins were mostly lysinerich histones, and almost no arginine-rich histones were extracted from the DNP at these low $\mathrm{NaCl}$ concentrations (Fig. 2b, c). At 0.4 $\mathrm{M} \mathrm{NaCl}$ (urea, $\mathrm{NaHSO}_{3}$ ) some arginine-rich histones could be extracted from the DNP although

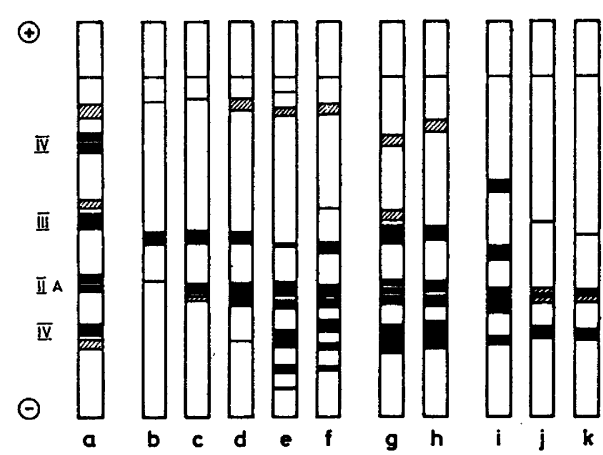

Fig. 2. Polyacrylamide gel electrophoresis. (a) Histones: IIA (intermediate histone fraction), II (lysine-rich), and IV (arginine-rich) from Sigma were dissolved in $10 \mathrm{M}$ urea, $0.9 \mathrm{M}$ acetic acid. (b-f) Bio-Gel A-50 separated free proteins in $10 \mathrm{M}$ urea, $0.9 \mathrm{M}$ acetic acid ( $c f$. Experimental) extracted from whole DNP with $6 \mathrm{M}$ urea, 0.04 $\mathrm{M} \mathrm{NaHSO}$ and increasing amounts of $\mathrm{NaCl}$ : (b) $0.2 \mathrm{M} \mathrm{NaCl}$, (c) $0.3 \mathrm{M} \mathrm{NaCl}$, (d) $0.4 \mathrm{M} \mathrm{NaCl}$, (e) $0.6 \mathrm{M} \mathrm{NaCl}$ and (f) $3 \mathrm{M} \mathrm{NaCl}$. $(\mathrm{g}-\mathrm{h}$ ) Histones extracted with acid from whole DNP in (g) $0.7 \times 10^{-3} \mathrm{M}$ potassium phosphate buffer, $\mathrm{pH}$ 8.0 and (h) $6 \mathrm{M}$ urea. ( $\mathrm{i}-\mathrm{k}$ ) Histones extracted with acid from partial DNP's, deproteinized with $6 \mathrm{M}$ urea, $0.04 \mathrm{M} \mathrm{NaHSO}_{3}$ and increasing amounts of $\mathrm{NaCl}$ : (i) $0.2 \mathrm{M} \mathrm{NaCl}$, (j) $0.3 \mathrm{M}$ $\mathrm{NaCl}$, and (k) $0.4 \mathrm{M} \mathrm{NaCl}$. The slowest moving band was bovine serum albumin. 
the fraction still consisted mainly of lysine-rich histones and intermediate histones (Fig. 2d). The extraction with $0.6 \mathrm{M} \mathrm{NaCl}$ (urea, $\mathrm{NaHSO}_{3}$ ) removed all the histones, even the arginine-rich ones (Fig. 2e), leaving $14 \%$ proteins, probably the non-histones, on the DNA core (Table 1). Even after extraction with $3 \mathrm{M} \mathrm{NaCl}$ (urea, $\mathrm{NaHSO}_{3}$ ) some of the proteins $(7 \%$ ) remain on DNA (Table 1). Fig. 2f depicts the electro. phoretic pattern of the histones dissociated at $3 \mathrm{M} \mathrm{NaCl}$ (urea, $\mathrm{NaHSO}_{3}$ ).

The salt-dissociated protein fractions were compared electrophoretically with the histones which remain on partially deproteinized DNP's. The electrophoresis of histones removed by acid extraction from whole freshly prepared chromatin is shown in Fig. 2g. An almost identical electrophoretic pattern was obtained for histones removed from chromatin in $6 \mathrm{M}$ urea (Fig. 2h). From this it is obvious that urea by itself does not remove histones from DNP.21 The electrophoresis of the histones that remain on the partially deproteinized DNP's shows that an increased amount of histones was removed as the $\mathrm{NaCl}$ concentration in urea- $\mathrm{NaHSO}_{3}$ solution was increased (Table 1 and Fig. 2 i-k). Lysine-rich and arginine-rich histones as well as

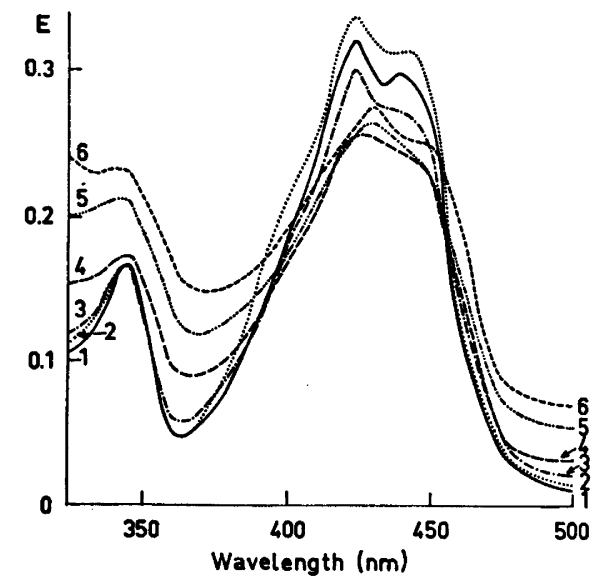

Fig. 3. Absorption spectra of quinacrine mustard mixed with whole deoxynucleoprotein. QM was mixed with different amounts of whole DNP in $0.7 \times 10^{-3} \mathrm{M}$ potassium phosphate buffer, $\mathrm{pH}$ 8.0 . (1) $0.033 \mathrm{mg} / \mathrm{ml} \mathrm{QM}$ alone, (2) $0.040 \mathrm{mg} / \mathrm{ml}$ DNP, (3) $0.072 \mathrm{mg} / \mathrm{ml} \mathrm{DNP,} \mathrm{(4)} 0.115 \mathrm{mg} / \mathrm{ml}$ DNP, (5) $0.150 \mathrm{mg} / \mathrm{ml} \mathrm{DNP}$ and (6) $0.200 \mathrm{mg} / \mathrm{ml}$ DNP. (The values of concentration refer to DNA plus proteins).

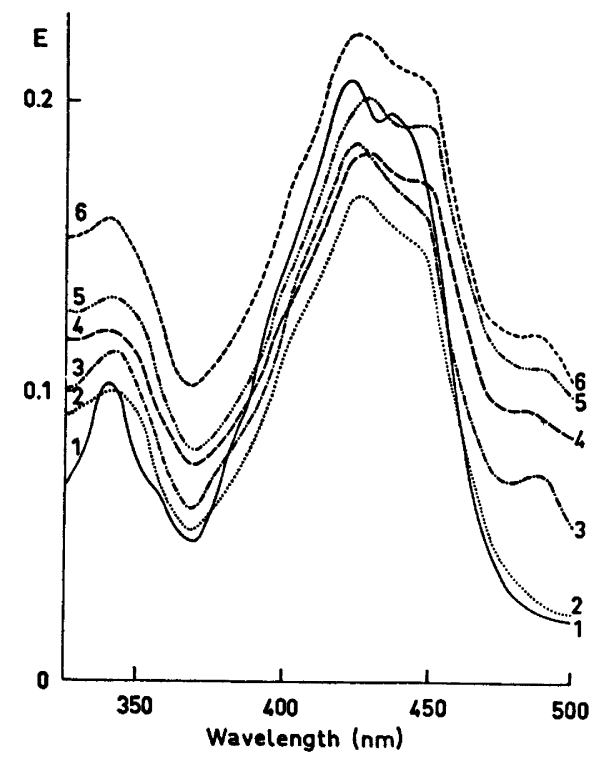

Fig. 4. Absorption spectra of quinacrine mustard bound to selectivity deproteinized deoxynucleoproteins. QM $(0.013 \mathrm{mg} / \mathrm{ml})$ was mixed with different partial DNP's $(0.025 \mathrm{mg} / \mathrm{ml})$ in $\mathbf{0 . 0 5}$ M Tris solution, pH 7.5. (1) QM alone, (2-6) partial DNP's from which the proteins were selectively removed by extraction with $6 \mathrm{M}$ urea, $0.04 \mathrm{M} \mathrm{NaHSO}_{3}$ and decreasing amounts of NaCl: (2) $3 \mathrm{M} \mathrm{NaCl}$, (3) $0.6 \mathrm{M} \mathrm{NaCl}$, (4) $0.4 \mathrm{M}$ $\mathrm{NaCl},(5) 0.3 \mathrm{M} \mathrm{NaCl}$ and (6) $0.2 \mathrm{M} \mathrm{NaCl}$.

intermediate histones remained on DNA after extraction with $0.2 \mathrm{M} \mathrm{NaCl}$ in urea- $\mathrm{NaHSO}_{3}$ (Fig. 2i). An almost complete absence of lysinerich histones was found on the DNA core after extraction with $0.3 \mathrm{M}$, respectively $0.4 \mathrm{M}, \mathrm{NaCl}$ in urea-NaHSO (Fig. 2j and 2k). No histones remained on DNA after extraction with 0.6 or $3 \mathrm{M} \mathrm{NaCl}$ in urea- $\mathrm{NaHSO}_{3}$ (not shown in the figure).

These data clearly show that the removal of the histones is complete at $0.6 \mathrm{M} \mathrm{NaCl}$ (urea, $\mathrm{NaHSO}_{3}$ ) and that almost all lysine-rich histones are removed with $0.4 \mathrm{M} \mathrm{NaCl}$ (urea, $\mathrm{NaHSO}_{3}$ ). These findings are in agreement with the results reported by Kleiman and Huang. ${ }^{21}$

The release of proteins from the DNP's is shown by an increase in the $260 \mathrm{~nm}$ to $280 \mathrm{~nm}$ ratio as well as in the $260 \mathrm{~nm}$ to $230 \mathrm{~nm}$ ratio (Table 1).

Absorption studies. The change in the absorption spectra of QM upon the addition of increasing amounts of whole DNP to the dye

Acta Chem. Scand. B 28 (1974) No. \& 
solution is shown in Fig. 3. Similar absorption spectra have also been recorded for QM complexed to DNA. ${ }^{14}$ At very lowDNP-to-dye ratios, however, there was an overall increase in the absorption spectra (Fig. 3, curve 2). A similar enhancement was found in the fluorescence intensity of QM mixed with whole DNP (cf. below). The shift of the absorption maximum from $424 \mathrm{~nm}$ to higher wavelengths is similar to the shift found with DNA. This shift and a isosbestic point at $455 \mathrm{~nm}$ are indicative of the formation of specific complexes of the dye with macromolecules (Fig. 3, curves 3-5).27 The absorption maximum at $345 \mathrm{~nm}$ is markedly increased. The fact that the isosbestic point is the same whether QM is bound to DNP or DNA suggests that the dye must interact in the same way with the two polymers. The step-by-step addition of polymers to other dyes in solution leads to similar changes in the absorption spectra of the dye tested. ${ }^{16,17}$

Similar changes occurred in the absorption spectra of QM with addition of partially deproteinized DNP's to the dye solution (Fig. 4). For DNP's from which the proteins have been removed with $0.3 \mathrm{M} \mathrm{NaCl}$ in urea- $\mathrm{NaHSO}_{3}$ (mostly the lysine-rich histones, Fig. 2c) the absorption maximum at $424 \mathrm{~nm}$ was reduced. However, the DNP fraction extracted with 0.2 $\mathrm{M} \mathrm{NaCl}$ (urea, $\mathrm{NaHSO}_{3}$ ) gave an overall enhancement of the absorption spectra of QM

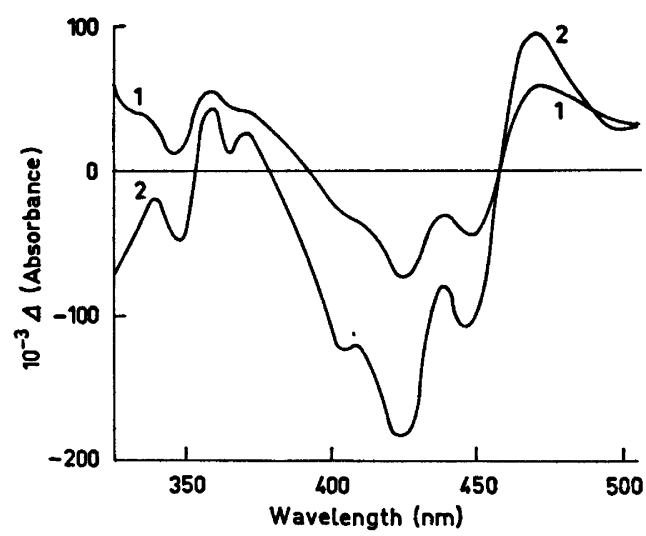

Fig. 5. Difference spectra of quinacrine and quinacrine mustard bound to whole deoxynucleoprotein. Whole DNP $(0.115 \mathrm{mg} / \mathrm{ml})$ was mixed with (1) $0.033 \mathrm{mg} / \mathrm{ml} \mathrm{QM}$ and (2) the same amount of $Q$ in $0.7 \times 10^{-3} \mathrm{M}$ potassium phosphate buffer, pH 8.0.

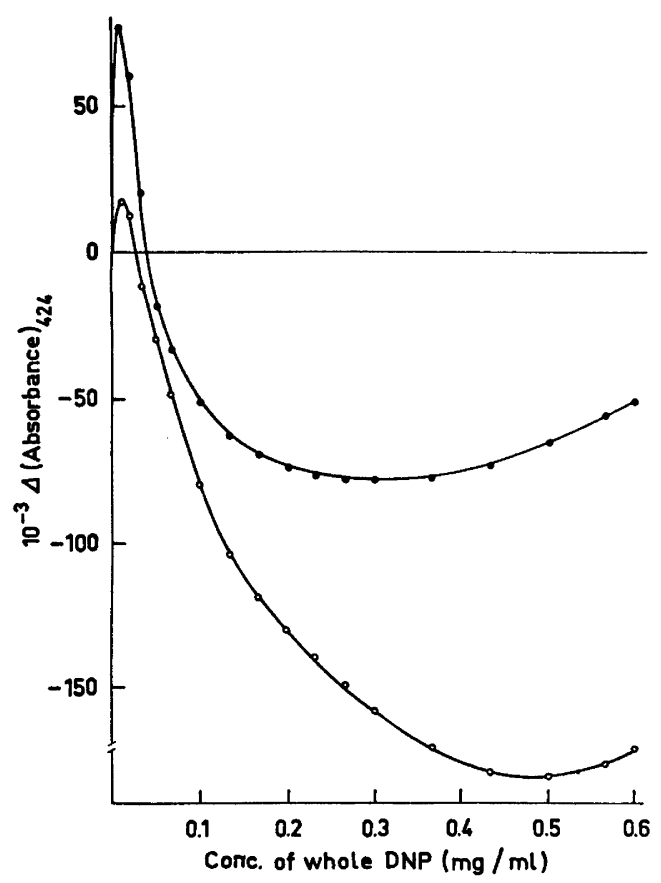

Fig. 6. Absorption properties of quinacrine and quinacrine mustard bound to whole deoxynucleoprotein. To a constant amount of $Q$ and QM $(0.033 \mathrm{mg} / \mathrm{ml})$ were added increasing amounts of whole DNP in $0.7 \times 10^{-3} \mathrm{M}$ potassium phosphate buffer, $\mathrm{pH}$ 8.0, Differences in the absorption maximum at $424 \mathrm{~nm}$ for (O) $Q$ and (O) QM were estimated.

(Fig. 4, curve 6). The same enhancement was found with whole DNP (Fig. 3, curve 2). The absorption spectra of QM was reduced the most with the DNP fraction extracted with $3 \mathrm{M} \mathrm{NaCl}$

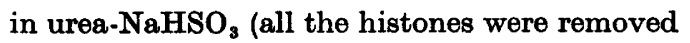
from the DNA core, Fig. 2f). When the amount of the proteins removed from the DNP increased (increased $\mathrm{NaCl}$ concentration in urea- $\mathrm{NaHSO}_{3}$ ), a corresponding increase in the ratio of absorp. tion at 424 and $365 \mathrm{~nm}$ was observed. For DNP extracted with $0.2 \mathrm{M} \mathrm{NaCl}$ (urea, $\mathrm{NaHSO}_{3}$ ) the 424 to $365 \mathrm{~nm}$ ratio was 2.15 whereas the corre. sponding value for DNP extracted with $3 \mathrm{M}$ $\mathrm{NaCl}$ (urea, $\mathrm{NaHSO}_{3}$ ) was 3.11.

Whole DNP alters the absorption spectra of $Q$, too. However, the absorption spectra of bound $Q$ differs from that of bound QM (Fig. 5). When equal amounts of $Q$ and $Q M$ was used, the spectra of $Q$ were more reduced upon the addition of whole DNP to the dye solution.

Acta Chem. Scand. B 28 (1974) No. 8 
The differences between these two dyes was particularly marked at wavelengths around the absorption maximum at $424 \mathrm{~nm}$ (Fig. 5).

The step-by-step addition of whole DNP to $Q$ or QM leads first to an enhancement of the absorption maximum at $424 \mathrm{~nm}$ (Fig. 6). However, DNP concentrations above 0.03 $\mathrm{mg} / \mathrm{ml}$ give a continuous reduction of the absorption maximum at $424 \mathrm{~nm}$. A much higher enhancement of the absorption maximum (424 $\mathrm{nm}$ ) was recorded in the QM-DNP mixtures than in the Q-DNP mixtures. However, the decrease of the absorption maximum is greater in the Q-DNP system than in the QM-DNP system. A DNP concentration of $0.4 \mathrm{mg} / \mathrm{ml}$ was still effective in reducing the absorption maximum of Q. However, only DNP concentrations below $0.2 \mathrm{mg} / \mathrm{ml}$ reduce the absorption maximum of QM, and further additions of whole DNP to the dye solution did not change the absorption maximum of bound QM at $424 \mathrm{~nm}$.

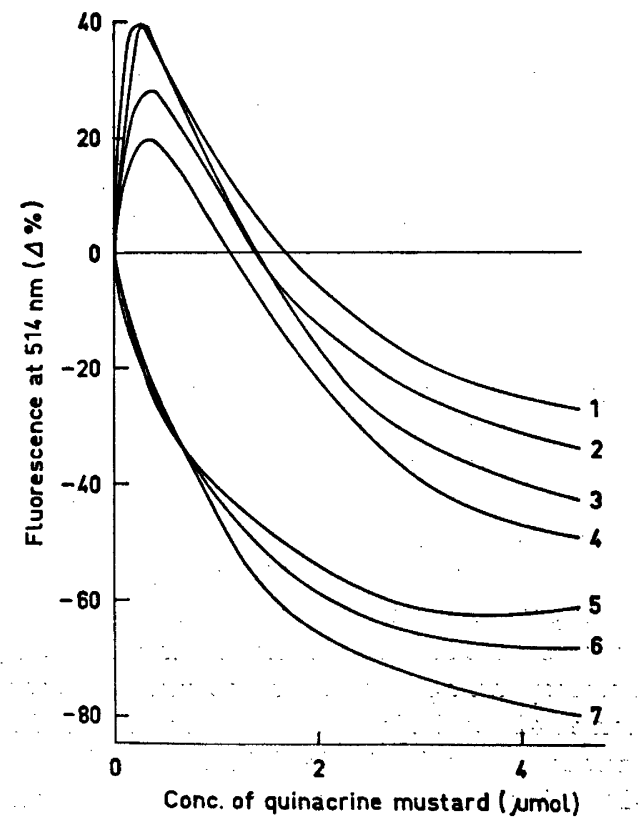

Fig. 7. Effect of DNA, whole and selectively deproteinized deoxynucleoproteins on the fluorescence intensity of quinacrine mustard. To a constant amount $(0.025 \mathrm{mg} / \mathrm{ml})$ of (1) whole DNP and partial DNP's extracted with (2) 0.2 $\mathrm{M} \mathrm{NaCl}$, (3) $0.3 \mathrm{M} \mathrm{NaCl}$, (4) $0.4 \mathrm{M} \mathrm{NaCl}$, (5) 0.6 $\mathrm{M} \mathrm{NaCl}$ and (6) $3 \mathrm{M} \mathrm{NaCl}$ in $6 \mathrm{M}$ urea, $0.04 \mathrm{M}$ $\mathrm{NaHSO}_{3}$, and (7) DNA, increasing amounts of $\mathrm{QM}$ in $0.05 \mathrm{M}$ Tris solution, $\mathrm{pH} \mathbf{7 . 5}$ were added.
At DNP concentrations above $0.35 \mathrm{mg} / \mathrm{ml}$ there was an increase in the absorption maximum of QM. These differences between the two dyes suggest that they must interact in different ways with the DNP. This is in line with the findings reported by Michelson et al. ${ }^{11}$ They showed differences in the interaction of $Q$ and QM with polynucleotides, particularly with $\operatorname{poly}(\mathrm{I}), \operatorname{poly}(\mathrm{dT})$, and poly(rU).

Fluorescence studies. The changes in the fluorescence intensity of QM bound to DNA, whole DNP, and partial DNP's are shown in Fig. 7. All the samples gave a net quench of the fluorescence intensity of the dye at high dye-to-polymer ratios. From the figure it is obvious that the samples can be divided into two separate groups. At high polymer-to-dye ratios, whole DNP and partial DNP's still con. taining arginine-rich histones. (extraction with 0.2 to $0.4 \mathrm{M} \mathrm{NaCl}$ in urea- $\mathrm{NaHSO}_{3}$, Fig. 2) enhanced the fluorescence intensity of the dye, whereas DNA and partial DNP's extracted.with $\geq 0.6 \mathrm{M} \mathrm{NaCl}$ (urea, $\mathrm{NaHSO}_{3}$ ) always quenched the fluorescence intensity of QM. It is evident that the proteins bound to DNA are able to

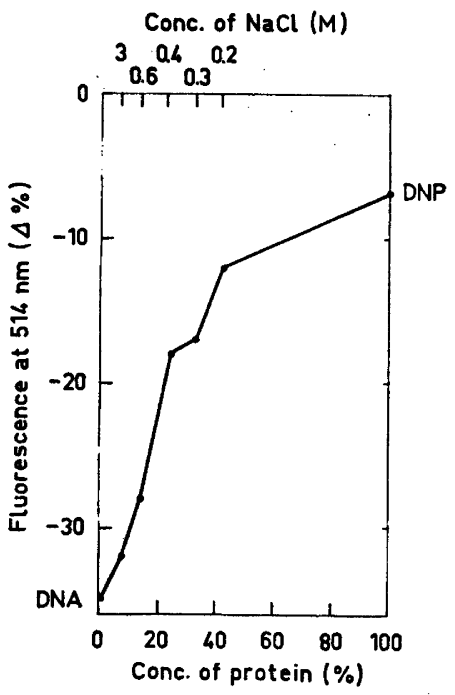

Fig. 8. Effect of selective removal of proteins from deoxynucleoprotein on the fluorescence intensity of quinacrine mustard. To a constant amount of polymer $(0.030 \mathrm{mg} / \mathrm{ml})$ was added QM $(0.013 \mathrm{mg} / \mathrm{ml})$ in $0.05 \mathrm{M}$ Tris solution, $\mathrm{pH}$ 7.5. The proteins were selectively removed with $0.2,0.3,0.4,0.6$, and $3 \mathrm{M} \mathrm{NaCl}$ in $6 \mathrm{M}$ urea and 0.04 $\mathrm{M} \mathrm{NaHSO}_{3}$ (cf. Experimental).

Acta Chem. Scand. B 28 (1974) No. 8, 
prevent the binding of the dye (steric hindrance). The histones are bound to the phosphate groups in DNA, ${ }^{28}$ thus also limiting the external ionic binding of the dye to negative phosphate groups. When the dye concentration was increased, the fluorescence intensity of the solution decreased as compared with the solution containing the dye alone. This is probably due to an interaction between proteins and the dye as well as to an increased dye-to-dye interaction. ${ }^{18,20}$

The effect of the quantity of the proteins in the DNP on the fluorescence intensity of QM is shown in Fig. 8. The fluorescence intensity of the dye was directly proportional to the amount of protein in the DNP. The curve was almost rectilinear between 0 and $42 \%$ protein in the DNP. The fluorescence intensity decreased by $75 \%$ when all histones $(86 \%$ in the whole DNP, Table 1) were removed from the DNP (extraction with $0.6 \mathrm{M} \mathrm{NaCl}$ in urea. $\mathrm{NaHSO}_{3}$ ). The extraction of the remaining proteins from the DNP (14\% in whole DNP, Table 1) accounts for the further decrease $(25 \%)$ of the fluorescence intensity of the dye. Thus the fluorescence intensity of nucleoproteinbound QM mostly depends on the tightly bound proteins, probably the non-histones, in the DNP. The quenching effect of native DNA on the fluorescence intensity of the dye was 5 times greater than that of whole DNP.

When whole DNP was added step-by-step to QM there was first an enhancement of the fluorescence intensity of the dye (Fig. 9). At

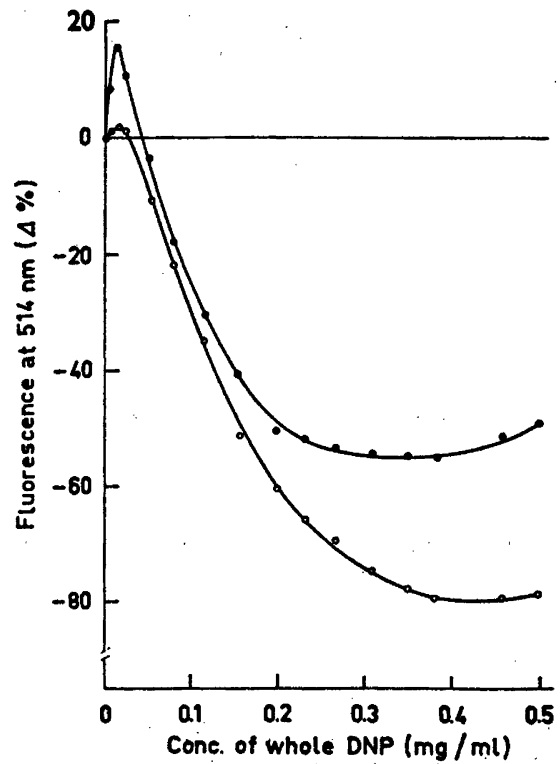

Fig. 9. Effect of whole deoxynucleoprotein on the fluorescence intensity of quinacrine and quinacrine mustard. To a constant amount of $(0.033 \mathrm{mg} / \mathrm{ml}) \mathrm{Q}(0)$ and $\mathrm{QM}(0)$ were added increasing amounts of whole DNP in $0.7 \times 10^{-3}$ M potassium phosphate buffer, $\mathrm{pH} 8.0$.

higher DNP concentrations ( $>0.4 \mathrm{mg} / \mathrm{ml}$ ), however, there was a quenching of the fluorescence intensity of QM until a plateau was obtained (approximately at $0.2 \mathrm{mg} / \mathrm{ml} \mathrm{DNP}$ in the solution).

Whole DNP enhanced and quenched the fluorescence intensity of $Q$, too (Fig. 9). The

Table 2. Amount of quinacrine mustard bound to DNA, whole DNP and partial DNP's from calf thymus. Extraction performed with urea, $\mathrm{NaHSO}_{3}$, and increasing amounts of $\mathrm{NaCl}$.

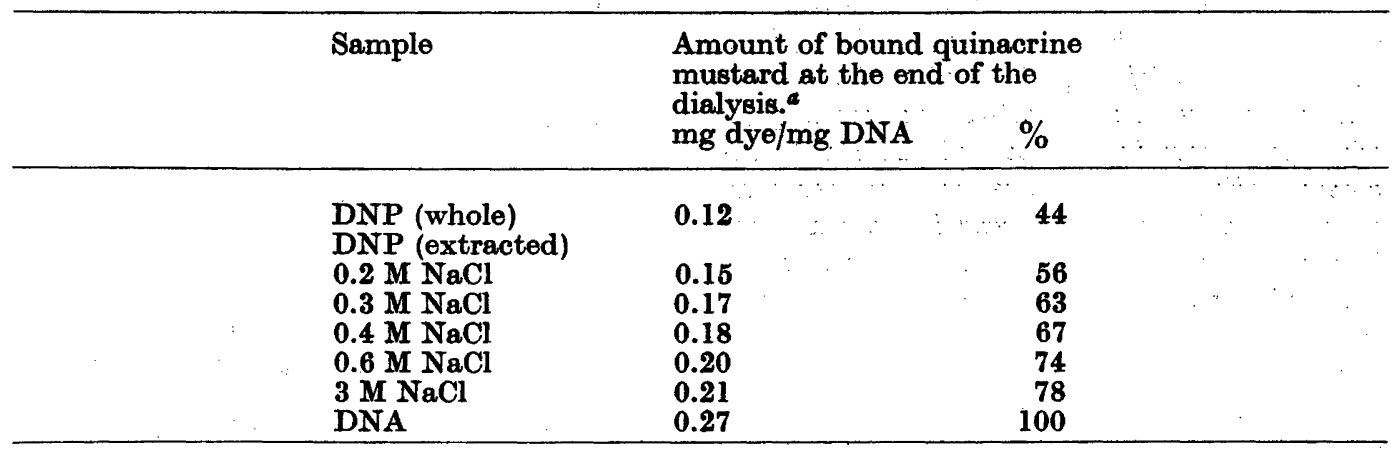

a Non-equilibrium dialysis was performed in $(5 \mathrm{ml}) 0.05 \mathrm{M}$ Tris solution, $\mathrm{pH} 7.54^{\circ} \mathrm{C}$ for $48 \mathrm{~h}$ with $0.020 \mathrm{mg} \mathrm{QM} / \mathrm{ml}$ and $0.025 \mathrm{mg}$ polymer $/ \mathrm{ml}$.

Acta Chem. Scand. B 28 (1974) No. 8 
Table 3. Effect of different protein fractions on the fluorescence intensity of quinacrine mustard in solution. ${ }^{a}$ Protein fraction obtained by extraction with urea, $\mathrm{NaHSO}_{3}$ and increasing amounts of $\mathrm{NaCl}$.

\begin{tabular}{|c|c|c|}
\hline $\begin{array}{l}\text { Conc. of } \mathrm{NaCl} \\
\text { (M) }\end{array}$ & $\begin{array}{l}\text { Fluorescence at } \\
514 \mathrm{~nm}(\Delta \%)\end{array}$ & Proteins in the fraction (cf. Fig. 2). \\
\hline $\begin{array}{l}0.2 \\
0.3\end{array}$ & $\begin{array}{l}+22 \\
+25\end{array}$ & \multirow{3}{*}{$\begin{array}{l}\text { lysine-rich histones } \\
\text { most lysine-rich and intermediate } \\
\text { histones } \\
\text { lysine-rich, intermediate and some } \\
\text { arginine-rich histones } \\
\text { all histones } \\
\text { all histones and some tightly bound } \\
\text { proteins (probably non-histones) }\end{array}$} \\
\hline 0.4 & +29 & \\
\hline $\begin{array}{l}0.6 \\
3\end{array}$ & $\begin{array}{l}+35 \\
+22\end{array}$ & \\
\hline
\end{tabular}

\footnotetext{
a Protein fractions $(0.025 \mathrm{mg} / \mathrm{ml})$ from partial DNP's were $\operatorname{mixed}$ with $\mathrm{QM}(0.007 \mathrm{mg} / \mathrm{ml}) \mathrm{in} 1 \%$
} acetic acid solution.

quenching effect on the fluorescence intensity of $Q$ was more marked than the effect on the fluorescence intensity of QM, particularly at high DNP.to-dye ratios (cf. Absorption studies). This probably indicates that more $Q$ is bound to the DNP than QM. Difference in the type of binding between $Q$ and $Q M$ have also been shown by Modest and Sengupta."30 They reported that QM binds approximately 25 times strongly to DNA as does $Q$, but fewer $Q M$ molecules, however, bind per unit length of DNA.

Binding studies. Non-equilibrium dialysis ${ }^{13}$ was used to estimate the amount of QM bound to DNA, whole DNP and partial DNP's (Table 2). The removal of the proteins from DNP led to an increase of approximately $50 \%$ in the amount of available binding sites in the DNA. DNP binds $0.12 \mathrm{mg}$ QM/mg DNA, while $1 \mathrm{mg}$ DNA binds $0.27 \mathrm{mg}$ dye. The greatest increase in the binding sites was found after the removal of proteins with $3 \mathrm{M} \mathrm{NaCl}$ (urea, $\mathrm{NaHSO}_{3}$ ) from the DNA core (cf. Fig. 8). These findings are unlike the results reported for binding of ethidium bromide to partial DNP's. ${ }^{16}$ The greatest effect on the interaction between ethidium bromide and DNP was found when the histone $f 1$ was extracted. Differences in the type of binding between acridine dyes and ethidium bromide have also been shown earlier.?

Interaction with proteins. The effect of the selectively dissociated protein fractions on the fluorescence intensity of QM was also tested (Table 3). All the protein fractions enhanced the fluorescence intensity of the dye. The greatest enhancement was obtained with the protein fraction containing all the histones (extracted from DNP with $0.6 \mathrm{M} \mathrm{NaCl}$ in urea$\mathrm{NaHSO}_{3}$ ). When most of the proteins were extracted (extraction with $3 \mathrm{M} \mathrm{NaCl}$ in urea. $\mathrm{NaHSO}_{3}$ ), the enhancement obtained was identical with that of the protein fraction containing only lysine-rich histones (extraction with 0.2 $\mathrm{M} \mathrm{NaCl}$ in urea-NaHSO${ }_{3}$, Fig. 2). This indicates

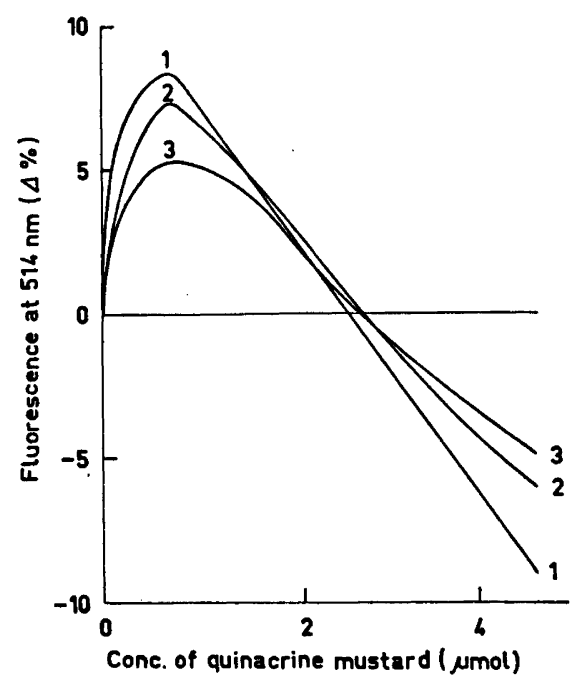

Fig. 10. Effect of artificial partial nucleohistones on the fluorescence intensity of quinacrine mus tard. To a constant amount $(0.025 \mathrm{mg} / \mathrm{ml})$ of $(1)$ DNA-IIA, (2) DNA-III and (3) DNA-IV were added increasing amounts of $\mathrm{QM}$ in $1 \mathrm{M} \mathrm{NaCl}$ solution (cf. Experimental).

Acta Chem. Scand. B 28 (1974) No. 8 
that the proteins which are hard to remove (probably the non-histones) prevent the enhancing effect of the histones on the fluorescence intensity of the dye. The enhancement of the fluorescence intensity of QM with different histone fractions agrees well with previous findings. ${ }^{13}$

Artificial nucleohistones. The effect of artificial DNP's on the fluorescence intensity of QM is shown in Fig. 10. The greatest quench of the fluorescence intensity of the dye was obtained with an artificial DNP composed of DNA and of an intermediate histone fraction (DNAIIA). A net enhancement of the fluorescence intensity of QM at low dye-to-polymer ratios was obtained with all three artificial DNP's. These curves differ from those obtained for natural DNP's ( $c f$. Fig. 7); structural differences between natural and artificial DNP's may account for the differences.

\section{DISCUSSION}

Absorption and fluorescence studies. When whole DNP was mixed with $Q$ or QM in solution an enhancement of the absorption maximum as well as of the fluorescence intensity of the two dyes was found. Several interpretations for this phenomenon are possible: (1) the binding mechanism between the dyes and the DNA core in the chromatin; (2) the interactions between the dyes and the proteins in the DNP samples; (3) the limiting of the ionic binding of the dyes by the proteins on the DNA core; (4) the blockade of the base specificity of the dyes by the proteins in the DNP.

The changes in the absorption and fluorescence properties of bound QM appear to be quite similar in DNA, whole DNP, and partial DNP's. This indicates that the binding processes are very similar for these different types of polymers. It is therefore possible that the first binding, at low dye-to-polymer ratios, is an intercalation of aromatic rings of the dye between the bases in the nucleohistone as first suggested with DNA. ${ }^{31}$ The second process, at increased dye concentrations in the solution, is an electrostatic interaction between the positive groups in the dye and the negative groups in DNP. The titration curves obtained when different DNP samples were mixed with QM in solution indicate that the fluorescence inten. sity is determined by the concentration ratio of the dye and DNP. At low dye concentrations the intercalation is dominant and there is an enhancement of the fluorescence intensity of QM, whereas at high dye concentrations the ionic bindings dominate and the fluorescence intensity of $\mathbf{Q M}$ is quenched.

In this paper it is shown that while all the major classes of chromosomal proteins inhibit the binding of QM to chromatin, the removal of the tightly bound proteins (extraction with 0.6 and $3 \mathrm{M} \mathrm{NaCl}$ in urea- $\mathrm{NaHSO}_{3}$ ) has the greatest effect on the binding of the dye to chromatin. In an earlier paper an interaction between the dye QM and calf thymus histones in solution has been reported. ${ }^{13}$ It is therefore likely that the dye also may be able to interact with proteins which cover the DNA core in the chromatin. Likely binding sites on the DNP are the carboxyl groups on the histones, since they are on the surface of the nucleoprotein complex. ${ }^{28}$

The binding sites for QM in whole DNP were reduced as compared to the binding sites for QM in native DNA. An increase of approximately $50 \%$ in the amount of bound QM was found when all the proteins were removed from the DNA core. Clark and Felsenfeld ${ }^{32}$ have shown that the proteins are not evenly distributed in the chromatin. They postulated that about half of the DNA is covered with proteins. Their conclusion corroborates other reports of dye-binding to chromatin. Klein and Szirmai ${ }^{15}$ found with the dye, azure $A$, that about the half of the DNA in the chromatin reacted with the dye. A similar dye-binding capacity suggesting that approximately $50 \%$ of the DNA is covered with proteins, has been reported by Angerer and Moudrianakis, ${ }^{16}$ Miura and Ohba, ${ }^{17}$ Ringertz and Bolund, ${ }^{33}$ Bolund, ${ }^{34}$ and Itzhaki. ${ }^{85,88}$ According to Phillips ${ }^{28}$ the negative charge of DNP is about $60 \%$ of that of DNA, i.e. about half of the negative groups of DNA are able to combine with the positive groups on cationic dyes in the DNP. The proteins on the DNA core reduce the amount of binding sites for the dye because the positive residues on the histones are bound to the negative groups in DNP, thus limiting the ionic binding of the dye. Since the proteins on the DNA core reduce the ionic binding sites between the dye and DNA, the fluorescence intensity for a QM-DNP

Acta Chem. Scand. B 28 (1974) No. 8 
mixture is higher than for a QM-DNA mixture.

The selective removal of proteins from whole DNP increases the quenching of the fluorescence intensity of QM in solution. However, at low dye-to-DNP ratios an enhancement of the fluorescence intensity of the dye was found with whole DNP and partially deproteinized DNP's still containing arginine-rich histones and other proteins (probably non-histones). These results indicate that the arginine-rich histones, which still covered the GC-rich regions in the DNA, prevent the quenching effect of GC-rich regions on the fluorescence intensity of QM. ${ }^{12}$ When all the histones were removed from the DNP, a net quench of the fluorescence intensity of the dye was found. The fluorescence intensity of QM as well as of $Q$ is highly depending on the base content of the DNA., $, 1,10-11,14$ When histones blockade bases in the DNA they are able to prevent the base specific interactions between the dyes and the bases in the DNA.

However, from the results in this paper it is not possible to say which one of the above given alternatives would explain why the absorption maximum or the fluorescence intensity was enhanced when the two dyes $Q$ and $Q M$ were mixed with whole DNP. Probably the phenomenon is caused by the action of all the alternatives together.

Comparison between $Q$ and $Q M$. The main difference of the two dyes $Q$ and $Q M$ is in the long aliphatic side chain at C-9. QM has an alkylating mustard group at the end of the side chain and is therefore able to bind chemically to polymers, whereas the binding of $Q$ is only through intercalation or electrostatic (cf. the structure of the two dyes).

Differences in the absorption and fluorescence properties were obtained when equal amounts of $Q$ and $Q M$ were mixed with whole DNP in solution. The absorption spectra of $Q$ was more reduced and the quenching effect on the fluorescence intensity of $Q$ was more marked upon the addition of whole DNP to the solution as compared with the effect of whole DNP on QM. These differences probably indicate that more $Q$ is bound to whole DNP than QM. This is in agreement with the results reported by Modest and Sengupta. ${ }^{30}$ When they compared the two dyes $\mathbf{Q}$ and $Q M$ they found that fewer QM molecules was bound to DNA.
Natural and artificial nucleohistones. A quite different picture emerged when artificial nucleohistones were mixed with QM in solution. Even arginine-rich complexes (the DNA-IV complex) were able to enhance the fluorescence intensity of the dye at low dye-to-polymer ratios. This reflects structural differences between natural and artificial nucleohistones. These differences might have resulted from the inability of the histones to interact properly with the DNA, i.e. the histones had assumed new positions on the DNA core. ${ }^{88}$ During the reconstitution a rearrangement of the proteins may occur. ${ }^{82}$ Angerer and Moudrianakis ${ }^{16}$ reported that the association constant for binding of ethidium bromide to natural DNP differs from the constant for the binding of the dye to artificially reconstituted DNP.

The fluorescence of metaphase chromosomes in situ. With the in situ hybridization technique it has been possible to determine the composi. tion of chromosomal DNA in some particular regions in eucaryotic chromosomes. AT-rich satellite DNA was found in the centromeric regions of the mouse chromosomes ${ }^{28}$ and in the secondary constrictions of the human chromosomes 1, 9, and 16.0 Saunders et al. ${ }^{40}$ were able to show a GC-rich satellite DNA in the secondary constriction in No. 9. Moreover cytochemical experiments indicate that regions staining brightly with $Q$ or QM contain AT-rich DNA, while regions with dull fluorescence contain GC-rich DNA. ${ }^{4-44}$ The mouse centromers and the secondary constrictions of human chromosomes 1, 9, and 16, however, show dull fluorescence when stained with quinacrine derivatives. These contradictory results, AT-richness and dull fluorescence, might be explained from the results in this paper.

Methanol-acetic acid fixed metaphase chro. mosomes contain very little protein ${ }^{45}$ Comings et al. ${ }^{45}$ showed that the fixative was not able to remove the non-histones. Therefore it can be assumed that the above mentioned chromosomal regions might be covered by non-histones which compete with the dye, thereby giving dull fluorescence. When metaphase slides were subjected to denaturation and reassociation and thereafter stained with QM, the centromeric regions of the mouse chromosomes as well as of the secondary constrictions in human chromosomes 1,9 , and 16 showed a bright fluorescence.

Acta Chem. Scand. B 28 (1974) No. 8 
This phenomenon can be explained by a possible extraction of proteins (non-histones) during the treatment in sodium hydroxide (denaturation) and the incubation in salt solution (reassociation). ${ }^{45}$ Protein dissociation might uncover the AT-rich regions, resulting in an enhancement of the fluorescence. At all the dye-to-polymer ratios tested, a quenching of the fluorescence intensity of QM was seen with DNP from which only the histones were removed (cf. Results). The other proteins, probably the non-histones, therefore may be able to prevent the effect of the bases in DNA on the fluorescence intensity of the dye.

Comings et al..$^{45}$ proposed that the nonhistone-DNA complexes contribute to the banding after $\mathrm{C}$ - and G-banding procedures. ${ }^{47}$ On the other hand recent findings of Zirkin ${ }^{48}$ showed an almost complete absence of non-histones in the heterochromatin in metaphase chromosomes from bovine kidney. It is therefore questionable whether bands reflect only the presence of non-histones. Secondary and tertiary configurations in the chromosomal macromole. cules may also contribute to the bands. Moreover, the degree and pattern of the base repetition apperently contribute to the occurrence of brighter and duller regions along the metaphase chromosomes..$^{18}$

In this paper it is shown that tightly bound proteins, probably the non-histones in the deoxynucleoprotein markedly affect the fluorescence intensity of QM in solution. The study of the effect of isolated non-histones in solution is underway in this laboratory.

Acknowledgements. I am very grateful to Dr. Albert de la Chapelle for valuable discussions and suggestions in connection with this work. Generous gifts of quinacrine and quinacrine mustard from the Sterling-Winthrop Research Institute are also acknowledged. This investigation was supported by grants from the Finnish National Research Council for Medical Sciences and the Sigrid Jusélius Foundation.

\section{REFERENCES}

1. Ris, H. In Lima-de-Faria, A., Ed., Handbook of Molecular Cytology, North-Holland, Amsterdam 1969, p. 221.

2. Georgiev, G. P. Annu. Rev. Genet. 3 (1969) 155.

Acta Chem. Scand. B 28 (1974) No. 8
3. Hearst, J. E. and Botchan, M. Annu. Rev. Biochem. 39 (1970) 151.

4. Ris, H. and Kubai, D. E. Annu. Rev. Genet. 4 (1970) 263.

5. Rigler, R., Jr. Acta Physiol.' Scand. 67 Suppl. 267 (1966) 1.

6. Weisblum, B. and de Haseth, P. I. Proc. Nat. Acad. Sci. U.S. 69 (1972) 629.

7. Weisblum, B: and de Haseth, P. L. Chromosomes Today 4 (1973) 35.

8. Houssier, C. and Fredericq, E. Biochim. Biophys. Acta 120 (1966) 434.

9. Gittelson, B. L. and Walker, I. O. Biochim. Biophys. Acta 138 (1967) 619.

10. Pachmann, U. and Rigler, R., Jr. Exp. Cell Res. 72 (1972) 602.

11. Michelson, A. M., Monny, C. and Kovoor, A. Biochimie 54 (1972) 1129.

12. Selander, R.-K. Biochem. J. 131 (1973) 749.

13. Selander, R.-K. and de la Chapelle, A. Biochem. J. 131 (1973) 757.

14. Selander, R.-K. Acta Chem. Scand. B 28 (1974) 45.

15. Klein, F. and Szirmai, J. A. Biochim. Biophys. Acta 72 (1963) 48.

18. Angerer; L. M. and Moudrianakis, E. N. $J$. Mol. Biol. 63 (1972) 505.

17. Miura, A. and Ohba, Y. Biochim. Biophys. Acta 145 (1967) 438.

18. Selander, R.-K. and de la Chapelle, A. Nature New Biol. 245 (1973) 240.

19. Zubay, G. and Doty, P. J. Mol. Biol. 1 (1959) 1 .

20. Marmur, J. J. Mol. Biol. 3 (1961) 208.

21. Kleiman, L. and Huang, R.-C. C. J. Mol. Biol. 64 (1972) 1.

22. Bonner, J., Chalkley, G. R., Dahmus, M., Fambrough, D., Fujimura, F., Huang, R.C. C., Huberman, J., Jensen, R., Marushige, K., Ohlenbusch, H., Oliver, B. and Widholm, J. Methods Enzymol. B 12 (1968) 3.

23. Kurnick, N. B. and Radcliffe, I. E. J. Lab. Clin. Med. 60 (1962) 669.

24. Burton, K. Biochem. J. 62 (1956) 315.

25. Lowry, O. H., Rosebrough, N. J., Farr, A. L. and Randall, R. J. J. Biol. Chem. 193 (1951) 265.

26. Panyim, S. and Chalkley, R. Biochemistry 8 (1969) 3972.

27. Dourlent, M. and Hélène, C. Eur. J. Biochem. 23 (1971) 86.

28. Phillips, D. M. P. Histones and Nucleohistones, Plenum Press, London 1971.

29. Azzi, A., Fabbro, A., Santato, M. and Gherardini, P. L. Eur. J. Biochem. 21 (1971) 404.

30. Modest, E. J. and Sengupta, S. K. In Casperson, T. and Zech, L., Eds., Chromosome Identification, Academic, New York 1973, p. 327.

31. Lerman, L. S. J. Mol. Biol. 3 (1961) 18.

32. Clark, R. J. and Felsenfeld, G. Nature New Biol. 229 (1971) 101.

33. Ringertz, N. B. and Bolund, L. Biochim. Biophys. Acta 174 (1969) 147. 
34. Bolund, L. Exp. Cell. Res. 63 (1970) 171.

35. Itzhaki, R. F. Biochem. Biophys. Res. Commun. 41 (1970) 25.

36. Itzhaki, R. F. Biochem. J. 122 (1971) 583.

37. Leng, M. and Felsenfeld, C. Proc. Nat. Acad. Sci. U.S. 56 (1966) 1325.

38. Corneo, G., Ginelli, E., Soave, C. and Bernardi, G. Biochemistry 7 (1968) 4373.

39. Corneo, G., Ginelli, E. and Polli, E. J. Mol. Biol. 48 (1970) 319.

40. Saunders, G. F., Shirakawa, S., Saunders, P. P., Arrighi, F. E. and Hsu, T. C. $J$. Mol. Biol. 63 (1972) 323.

41. Ellison, J. R. and Barr, H. J. Chromosoma 36 (1972) 375.

42. Dev, V. G., Warburton, D., Miller, O. J., Miller, D. A., Erlanger, B. F. and Beiser, S. M. Exp. Cell. Res. 74 (1972) 288.

43. Schreck, R. R., Warburton, D., Miller, $O$. J., Beiser, S. M. and Erlanger, B. F. Proc. Nat. Acad. Sci. U.S. 70 (1973) 804.

44. de la Chapelle, A., Schröder, J., Selander, R.-K. and Stenstrand, K. Chromosoma 42 (1973) 365.

45. Comings, D. E., Avelino, E., Okada, T. A. and Wyandt, H. E. Exp. Cell Res. 77 (1973) 469.

46. de la Chapelle, A., Schröder, J. and Selander, R.-K. Hereditas 69 (1971) 149.

47. Paris Conference (1971): Standardization in Human Cytogenetics. Birth Defects: Original Article Series VIII: 7, The National Foundation, New York 1972.

48. Zirkin, B. R. Exp. Cell Res. 78 (1973) 394.

Received April 3, 1974. 